Chem 216:14539-14544

24. De Prins FA, Hill DJ, Fekete M, Robsen DJ, Fieller NRJ, Van Assche FA, Milner RDG 1984 Reduced plasma somatomedin activity and costal cartilage sulfate incorporation activity during experimental growth retardation in the fetal rat. Pediatr Res 18:1100-1104

25. Vileisis RA, D'Ercole AJ 1986 Tissue and serum concentrations of somatomedin-C/insulin-like growth factor-I in fetal rats made growth retarded by uterine artery ligation. Pediatr Res 20:126-130

26. Romanus JA, Terrell JE, Yang YW-H, Nissley SP, Rechler MM 1986 Insulinlike growth factor carrier proteins in neonatal and adult rat serum are immunologically different: demonstration using a new radioimmunoassay for the carrier protein from BRL-3A rat liver cells. Endocrinology 118:17431758

27. D'Ercole AJ, Wilkins JR 1984 Affinity labeled somatomedin-C binding proteins in rat sera. Endocrinology 114:1141-1144

28. Martin JL, Baxter RC 1985 Antibody against acid-stable insulin-like growth factor binding protein detects $150,000 \mathrm{~mol}$ wt growth hormone-dependent complex in human plasma. J Clin Endocrinol Metab 61:799-801

29. White RM, Nissley SP, Short PA, Rechler MM, Fennoy I 1982 Developmental pattern of a serum binding protein for multiplication stimulating activity in the rat. J Clin Invest 69:1239-1252
30. Kiess W, Greenstein LA, White RM, Lee L, Rechler MM, Nissley SP 1987 Type II insulin-like growth factor receptor is present in rat serum. Proc Natl Acad Sci USA 84:7720-7724

31. Sara VR, Menolascino S, Sjögren B, Wetterberg L, Muntzing K, Oldfors A, Sourander P 1986 The influence of maternal protein deprivation on the developmental pattern of serum immunoreactive insulin-like growth factor I (IGF-I) levels. Acta Physiol Scand 126:391-395

32. Powell DR, Rosenfeld RG, Sperry JB, Baker BK, Hintz RL 1987 Serum concentrations of insulin-like growth factor (IGF)-I, IGF-2 and unsaturated somatomedin carrier proteins in children with chronic renal failure. Am $\mathbf{J}$ Kidney Dis 10:287-292

33. Hall K, Lundin G, Povoa G 1988 Serum levels of the low molecular weight form of insulin-like growth factor binding protein in healthy subjects and patients with growth hormone deficiency, acromegaly and anorexia nervosa. Acta Endocrinol (Copenh) 118:321-326

34. Brismar K, Gutniak M, Povoa G, Werner S, Hall K 1988 Insulin regulates the $35 \mathrm{kDa}$ IGF binding protein in patients with diabetes mellitus. J Endocrinol Invest 11:599-602

35. Suikkari A-M, Koivisto VA, Rutanen E-M, Yki-Jarvinen H, Karonen S-L, Seppala M 1988 Insulin regulates the serum levels of low mol wt insulin-like growth factor-binding protein. J Clin Endocrinol Metab 66:266-272

\title{
Announcement
}

\section{NIH CONSENSUS DEVELOPMENT CONFERENCE: TREATMENT OF DESTRUCTIVE BEHAVIORS IN PERSONS WITH DEVELOPMENTAL DISABILITIES}

A Consensus Development Conference on Treatment of Destructive Behaviors in Persons with Developmental Disabilities will be held in Masur Auditorium in the Warren Grant Magnuson Clinical Center, National Institutes of Health, Bethesda, MD, September 11-13, 1989. This open forum will focus on the various treatments and approaches used to modify or eliminate destructive behaviors in persons with developmental disabilities.

On the first 2 days, experts will present current scientific thinking about the diagnosis, management, and prevention of destructive behaviors in persons with developmental disabilities, and concerned voluntary organizations will be invited to make statements. On the $3 \mathrm{rd}$ day, after considering the scientific evidence, the consensus panel will present its draft report and invite comments from the audience. Dr. R. Rodney Howell, Professor and Chairman, Department of Pediatrics at the University of Miami School of Medicine, will chair the panel.

For further information and registration contact Ms. Barbara McChesney, Prospect Associates, Suite 500, 1801 Rockville Pike, Rockville, MD 20852 (301) 468-6555. 